\title{
TEHNIK PENINGKATAN IMUNITAS JIWA DAN PENERAPAN PROTOKOL KESEHATAN DALAM PERSIAPAN KEGIATAN PEMBELAJARAN SAAT ERA NEW NORMAL
}

DOI: https://doi.org/10.33024/jkpm.v4i4.4007

\author{
Bagus Dwi Cahyono ${ }^{1 *}$, Nurul Huda ${ }^{2}$, Evy Aristawati ${ }^{3}$ \\ 1,2,3 Universitas Jember Kampus Kota Pasuruan \\ Disubmit: 11 Maret 2021 Diterima: 07 April $2021 \quad$ Diterbitkan: 03 Agustus 2021
}

Email Korespondensi: bagusdwi.akper@unej.ac.id

\begin{abstract}
ABSTRAK
Kondisi pandemic Covid-19 merubah dunia, hal yang tidak lazim menjadi lazim. Semua kegiatan dilakukan dari rumah, hal ini memicu seseorang mengalami stress dan menurunkan imun dalam tubuh. Kondisi pandemic memaksa remaja melakukan semua kegiatan di rumah. Remaja rentan mengalami stress, hal ini bisa menurunkan daya tahan tubuhnya dan lebih rentan sakit. Jika remaja sering mengalami sakit, maka akan mempengaruhi proses pertumbuhan dan perkembangannya. Orang tua memiliki peranan penting dalam menjaga kondisi anaknya. Pandemic Covid-19 mengharuskan pembelajaran dilakukan secara online, tapi di Madin Al Muhajirin pembelajaran dilakukan dengan tatap muka karena sudah masuk zona hijau. Pemberian pengetahuan dan latihan tehnik peningkatan imunitas jiwa serta penerapan protocol kesehatan dalam kegiatan pembelajaran saat new normal era adalah hal yang harus segera dilakukan agar santri memiliki pengetahuan serta terampil menerapkan terapi aktivitas kelompok serta penerapan protocol kesehatan baik dilakukan di rumah maupun di lingkungan madrasah diniyah. Metode yang digunakan dalam pengabdian ini adalah penyuluhan pada 27 santri. Hasil evaluasi sebagian besar santri $(80 \%)$ memahami dan mengerti tentang dan mampu mempraktekkan cara cuci tangan, menggunakan masker dan melepas masker, serta melakukan kegiatan terapi aktivitas kelompok.
\end{abstract}

Kata Kunci : imunitas jiwa, protokol kesehatan, pembelajaran new normal

\begin{abstract}
The conditions of the Covid-19 pandemic have changed the world; things that are not uncommon are becoming commonplace. All activities are carried out from home; this triggers a person to experience stress and lowers immunity in the body. Pandemic conditions force teenagers to do all activities at home. Teenagers are prone to anxiety; this can reduce their immune system and are more prone to illness. If adolescents often experience illness, it will affect the process of growth and development. Parents have an essential role in maintaining the condition of their children. The Covid-19 pandemic requires learning to be done online, but at Madin Al Muhajirin, learning is done face-toface because it has entered the green zone. Giving knowledge and training in
\end{abstract}


mental immunity enhancement techniques and implementing health protocols in learning activities during the new normal era must be done immediately so that students can implement group activity therapy and implement health protocols both at home and in Madrasah Diniyah circles. The method used in this service was counseling 27 students. The results of the evaluation most of the students (80\%) understand and understand about and can practice how to wash hands, use masks and remove masks, and carry out group therapy activities.

Keywords : mental imunity, health protocol, new normal learning

\section{PENDAHULUAN}

Sejak pandemic Covid-19 banyak yang berubah, mulai dari perubahan fisik, psikologis anggota keluarga serta perubahan ekonomi. Kegiatan masyarakat di batasi dan hanya usaha yang bergerak di bidang kesehatan serta yang berhubungan dengan pangan yang masih di ijinkan beroperasional. Sekolah di tutup, dan kegiatan pembelajaran dilakukan secara online dari rumah. Semua kegiatan di lakukan di rumah, termasuk kegitan bermain. Dengan perubahan yang tidak lazim ini memberikan dampak pada semua orang termasuk remaja. Perubahan ini memberikan dampak pada kondisi mental remaja, dimana masa remaja yang lebih senang bersama dengan temannya tidak lagi bisa dinikmati. Masa new normal memaksa semua orang melakukan kegiatan dari rumah dan menerapkan protocol kesehatan. Remaja yang hanya melakukan kegiatan di rumah saja dapat menimbulkan stress sehingga mempengaruhi imunitas tubuh yang menurun. Hal ini memicu kesehatan remaja baik secara fisik maupun secara mental (Rizkiana, dkk., 2020).

Menurut Idris, dkk (2020) bahwa 34,6\% responden mengunjungi rumah sakit dan klinik dan sisanya tidak berani memanfaatkan fasilitas kesehatan di kondisi pandemic. Hasil penelitian Zang, et al (2020) mengatakan bahwa Covid-19 memberikan dampak psikologis sosial yang serius terutama pada orang yang dilakukan karantina, akses terbatas dan menyarankan pengmbangan sistem respon intervensi krisis psikologis yang lebih komprehensif untuk masalah sosial dan psikologis yang mendesak. Penelitian yang dilakukan Dong, et al (2020) menyimpulkan bahwa Covid-19 telah memberikan dampak psikologis stress serta kehawatiran tentang kesehatan fisik dan dibutuhkan dukungan psikologis untuk mengatasi stress akibat Covid19.

Remaja masih dalam tahap berkembang. hal ini mempengaruhi sistem kekebalan tubuhnya dan remaja lebih rentan sakit. Jika remaja sering mengalami sakit, maka akan mempengaruhi proses pertumbuhan dan perkembangannya sehingga tidak bisa berjalan secara optimal. Peran orang tua sangat penting dalam menjaga daya tahan tubuh anaknya agar tetap sehat. Kondisi pandemic Covid-19 imunitas tubuh memiliki peran penting dalam melindungi tubuh dari penularan virus Covid-19. Dengan sistem imun yang kuat, maka pertahanan tubuhnya juga optimal dalam melawan bakteri, parasit, jamur maupun virus penyebab suatu penyakit. Remaja merupakan harapan bangsa dalam meneruskan pembangunan, jika remaja sehat baik fisik maupun mental, maka pembangunan bisa berjalan optimal (Sutrio, 2017)

Madin Al Muhajirin Pandaan merupakan madrasah diniyah yang melakukan proses pembelajaran setiap hari mulai jam 13.00-16.00 WIB. Di kondisi pandemic Covid-19, Madin masih melakukan pembelajaran dengan tetap menerapkan protokol kesehatan. Kondisi pandemic yang mengharuskan 
sekolah di tutup membuat santri stress tidak bisa melakukan aktivitas di luar rumah. Pemberian pengetahuan tentang tehnik meningkatkan imunitas di masa pandemic serta kegiatan terapi aktivitas kelompok sangat bermanfaat untuk menurunkan stress dan meningkatan daya tahan tubuh. Penerapan protokol kesehatan dengan melatih cara cuci tangan yang benar di harapkan bisa meminimalkan penularan Covid-19 dan perilaku ini bisa di tularkan pada anggota keluarga santri Madin (Meisyaroh, dkk., 2021).

Kegiatan pengabdian kepada masyarakat ini bertujuan agar santri Madin memiliki ketrampilan terapi aktivitas kelompok untuk meningkatkan imunitas dalam tubuhnya serta menerapkan protokol kesehatan yang tepat sehingga dapat terlibat aktif dalam mengendalikan penularan Covid 19. Sesuai latar belakang, kegiatan pengabdian ini dengan memberikan pendidikan kesehatan tentang tehnik peningkatan imunitas jiwa dan penerapan protokol kesehatan dalam persiapan kegiatan pembelajaran saat new normal era di Madin Al Muhajirin Pandaan Kabupaten Pasuruan Jawa Timur.

\section{MASALAH}

Pemilihan tempat pengabdian di Madin Al Muhajirin adalah di kondisi pandemic Madin masih melakukan pembelajaran tatap muka. Tempat Madin berada di pedesaan, dimana tingkat pengetahuan warga masih rendah ditandai dengan ditemukannya beberapa permasalahan seputar kesehatan diantaranya adalah belum mematuhi penerapan protokol Kesehatan dalam kehidupan sehari-hari. Pengabdian kepada masyarakat yang diberikan ini di harapkan santri mampu melakukan terapi aktivitas kelompok untuk menurunkan stress sehingga imunitas meningkat serta mampu menerapkan protocol kesehatan di mana saja, baik di lingkungan Madin maupun ketika sudah di rumah.

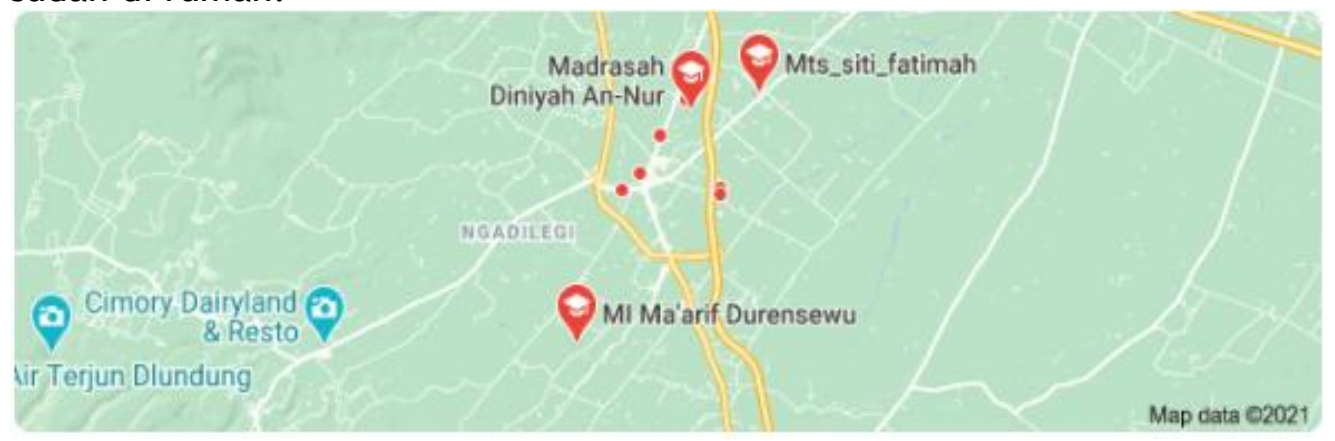

Gambar 2.1 Peta Lokasi Kegiatan

\section{METODE}

Metode yang di gunakan dalam kegiatan ini adalah metode penyuluhan. Kegiatan awal yang dilakukan sebelum kegiatan penyuluhan adalah pembukaan oleh Kepala Sekolah Madin Al Muhajirin. Dilanjutkan dengan perkenalan, menjelaskan tujuan dari kegiatan penyuluhan serta menggali tingkat pengetahuan santri seputar protokol kesehatan di masa pandemic. Kegiatan selanjutnya adalah penyampaian materi, sesi diskusi, pemutaran video. latihan terapi aktivitas kelompok untuk meningkatkan imunitas, latihan cuci tangan, penggunaan masker serta hand sanitizaer. Media yang digunakan dalam penyuluhan ini adalah LCD untuk pemaparan teori, alat cuci tangan, masker, hand sanitizer untuk kegiatan praktek. Di akhir kegiatan ini adalah 
melakukan evaluasi materi yang di sampaikan, meminta santri untuk mempraktekkan cara cuci tangan, memakai masker serta menyimpulkan dari materi yang sudah di sampaikan.

\section{HASIL DAN PEMBAHASAN}

Penyuluhan ini dilaksanakan selama 1 hari dan di ikuti oleh perwakilan santri sebanyak 27 orang. Selama berlangsungnya kegiatan, peserta terlihat antusias mendengarkan dan aktif berdiskusi. Pada awal penyampaian materi, pemateri meminta peserta untuk menyampaikan pengetahuannya tentang tips meningkatkan imunitas, serta penerapan protocol kesehatan guna mencegah penularan Covd-19, dilanjutkan dengan latihan terapi aktivitas kelompok, praktek cara cuci tangan, cara menggunakan dan melepas masker. Hasil evaluasi sebagian besar santri $(80 \%)$ memahami dan mengerti tentang dan mampu mempraktekkan cara cuci tangan, menggunakan masker dan melepas masker, serta melakukan kegiatan terapi aktivitas kelompok. Peserta senang dengan penyuluhan ini, hal ini terbukti dengan banyaknya peserta yang aktif dalam diskusi dan mengajukan pertanyaan serta antusias ketika ditanya seputar tips meningkatkan imunitas serta mampu mempraktekkan cara cuci tangan yang benar serta melakukan terapi aktivitas kelompok. Gambar kegiatan pengabdian sebagai berikut :

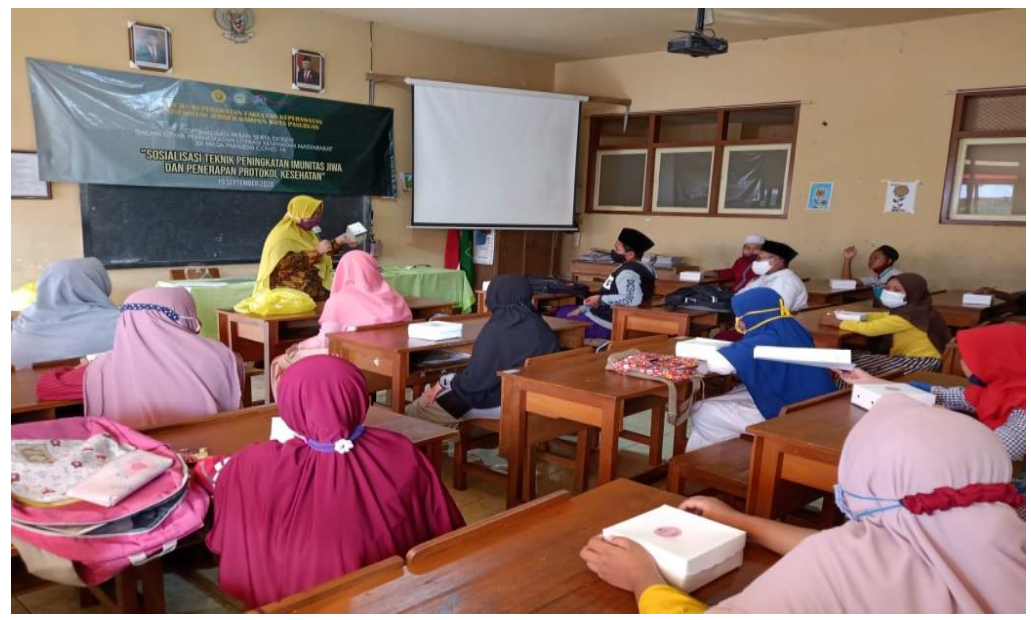

Gambar 4.1 Kegiatan Menyampaikan Materi

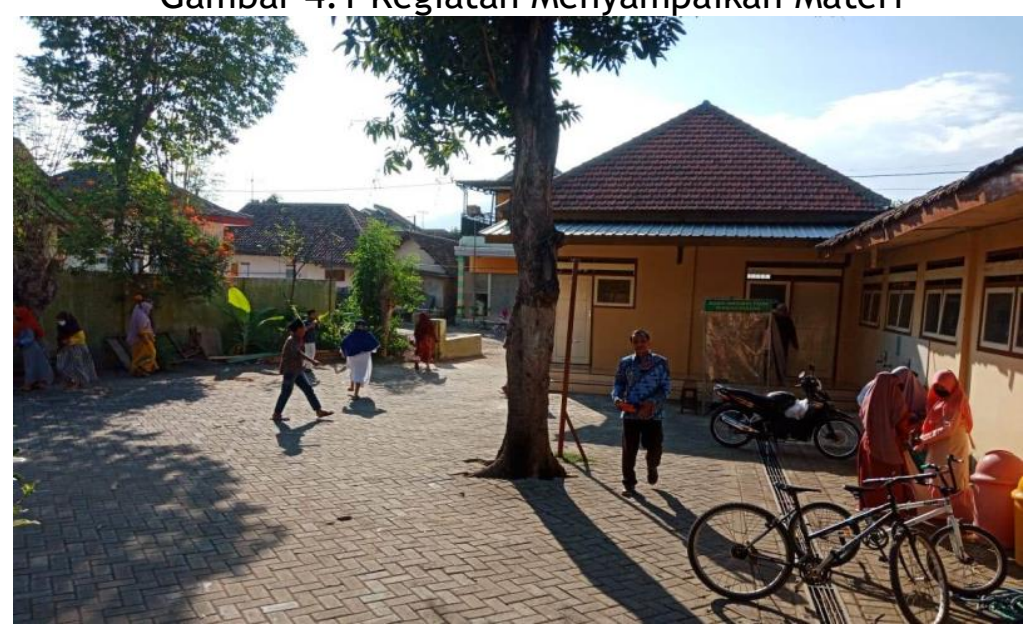

Gambar 4.2 Sesi TAK 


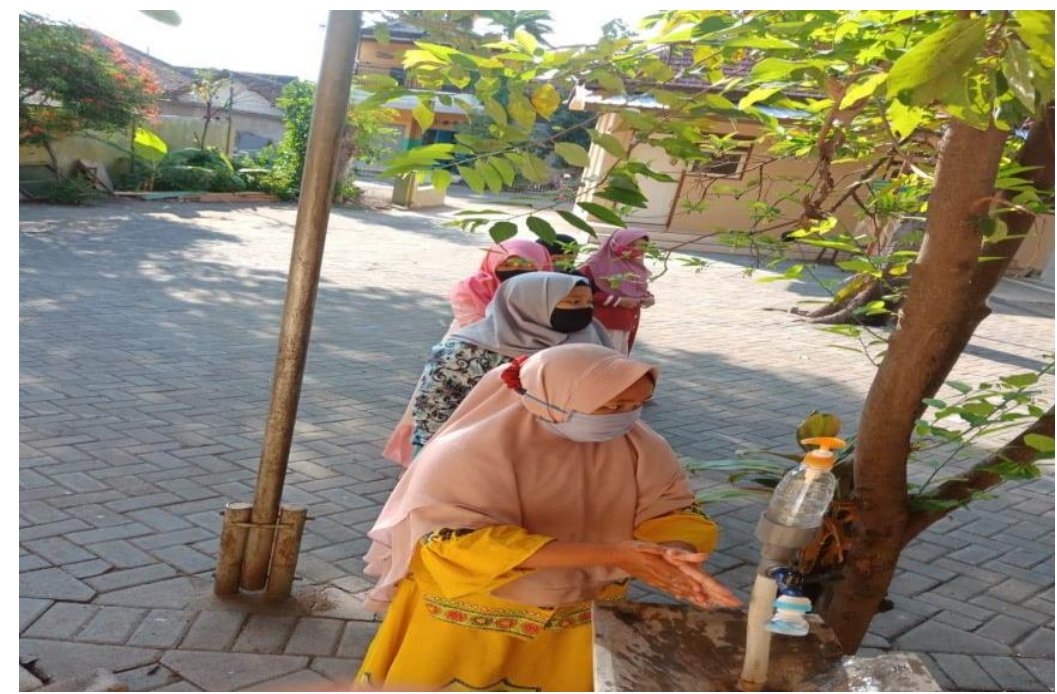

Gambar 4.3 Sesi Latihan Cuci Tangan

\section{KESIMPULAN}

Kesimpulan dari kegiatan penyuluhan ini adalah seluruh santri Madin aktif mengikuti kegiatan mulai penyampaian materi, latihan terapi aktivitas kelompok, latihan cuci tangan, penggunaan masker serta handsanitizer dan mengikuti kegiatan sampai selesai. Terjadi perubahan pengetahuan dari apersepsi santri yang belum mengetahui tentang cara meningkatkan imunitas serta penerapan protocol kesehatan ketika evaluasi terjadi peningkatan pengetahuan santri serta mampu mempraktekkan cuci tangan yang benar, menggunakan dan melepas masker yang benar, melakukan terapi aktivitas kelompok dengan tepat. Santri juga mampu mengingatkan temannya ketika menggunakan masker tidak benar serta tidak cuci tangan sebelum dan setelah kegiatan sesuai dengan hasil penyuluhan yang didapat.

\section{DAFTAR PUSTAKA}

Ali, M., \& Asrori, M. (2010). Psikologi Remaja. Jakarta : Bumi Aksara.

Dong, Z.Q., Ma, J., Hao, Y.N., Shen, X.L., Liu, F., Gao, Y., \& Zhang, L. (2020).

The Social Psychological Impact of the Covid-19 Pandemic on Medical Staff in China: A Cross-Sectional Study. European Psychiatry, 63 (1), E65, doi:10.1192/j.eurpsy.2020.59.

Idris, A.M., Mustakim., Fajrini, F., Latifah, N. (2020). Gambaran Persepsi Pasien Terhadap Implementasi Pelayanan Kesehatan selama masa Pandemik COVID-19 di Wilayah Kota Depok Tahun 2020. Holistik Jurnal Dunia Kesmas, 9 (4), 470-479, doi: https://doi.org/10.33024/jdk.v9i4.3212.

Li, W., Yang, Y., Liu, Z.H., Zhao, Y.Z., Zhang, Q., Zhang, L., Cheung, T., \& Xiang, Y.T. (2020). Progression of Mental Health Services during the Covid-19 Outbreak in China. Int J Bio Sci, 16 (10), 1732-1738, doi:10.7150/ijbs. 45120.

Meisyaroh, M.S., Sakinah, S., Asnudin., Nurdin, S., Hasrul., \& Murtini. (2021). Penyuluhan Cuci Tangan Pakai Sabun (CTPS) dan Penanganan Covid-19. Jurnal Kreativitas Pengabdian Kepada Masyarakat (PKM), 4 (1), 234239, doi: https://doi.org/10.33024/jkpm.v4i1.3835. 
Pawiliyah., Fernaliyah., Adriansyah, F., Saleh., \& Yuliyanti, S. (2020). Sosialisasi Transaksi Jual Beli Aman Terhadap Covid 19 Memasuki Fase New Normal Di Pasar Tradisional Kota Bengkulu. Jurnal Kreativitas Pengabdian Kepada Masyarakat (PKM), 3 (2), 415-421, doi: https: //doi.org/10.33024/jkpm.v3i2.3340.

Rachul, C., Marcon, A.R., Collins, B., \& Caulfield, T. (2020). Covid-19 and Immune Boosting on the Internet: A Content Analysis of Google Search Results. BMJ Open, 10 (10), e040989. doi:10.1136/ bmjopen-2020040989.

Rasman, R., \& Nurdian, Y. (2020). Inisiasi Pelatihan Tari Sebagai Terapi Pereda Depresi Anak Saat Pandemi Di Taddan Sampang. Jurnal Kreativitas Pengabdian Kepada Masyarakat (PKM), 3 (2), 474-479, doi: https: / /doi.org/10.33024/jkpm.v3i2.3006.

Sadock ,J.B., \& Sadock, A.V. (2010). Kaplan \& Sadock Buku Ajar Psikiatri Klinis Edisi ke-2. Jakarta : EGC .

Surmiasih., Winarsih, N., \& Wahidun. (2019). Pendidikan Kesehatan terhadap Kemampuan Remaja Putri dalam Perawatan Organ Reproduksi. Holistik Jurnal Kesehatan, 13 (1), 76-83, doi: https://doi.org/10.33024/hjk.v13i1.1045.

Sutrio. (2017). Hubungan Asupan Energi, Pengetahuan Gizi Dan Aktivitas Fisik Terhadap Status Gizi Siswa Sekolah Menengah Atas Global Madani Kota Bandar Lampung Tahun 2016. Holistik Jurnal Kesehatan, 11 (1), 1-4, doi: https://doi.org/10.33024/hjk.v11i1.122.

Wagner, D.N., Marcon, A.R. \& Caulfield, T. (2020). Immune Boosting in the Time of COVID: Selling Immunity on Instagram. Allergy Asthma Clin Immunol, 16 (76), doi: https://doi.org/10.1186/s13223-020-00474-6.

Zhang, J., Wu, W., Zhao, X., \& Zhang, W. (2020). Recommended Psychological Crisis Intervention Response to the 2019 Novel Coronavirus Pneumonia Outbreak in China: a Model of West China Hospital. Precision Clinical Medicine, 3 (1), 3-8, doi: https://doi.org/10.1093/pcmedi/pbaa006. 